\title{
Health literacy of adults with and without arterial hypertension
}

\author{
Letramento em saúde de adultos com e sem hipertensão arterial \\ Alfabetización en salud de adultos con y sin hypertension
}

\section{Fernanda Moura Borges' \\ ORCID: 0000-0002-8588-0224}

Ana Roberta Vilarouca da Silva' ORCID: 0000-0001-5087-4310

Luisa Helena de Oliveira Lima' ORCID: 0000-0002-1890-859X

Paulo César de Almeida" ORCID: 0000-0002-2867-802X

Neiva Francenely Cunha Vieira"'

ORCID: 0000-0002-9622-2462

Ana Larissa Gomes Machado' ORCID: 0000-0002-7937-6996

'Universidade Federal do Piauí. Picos, Piauí, Brasil. "Universidade Estadual do Ceará. Fortaleza, Ceará, Brasil. I'Universidade Federal do Ceará. Fortaleza, Ceará, Brasil.

How to cite this article: Borges FM, Silva ARV, Lima LHO, Almeida PC, Vieira NFC, Machado ALG. Health literacy of adults with and without arterial hypertension. Rev Bras Enferm. 2019;72(3):645-53. doi: http://dx.doi.org/10.1590/0034-7167-2018-0366

\section{Corresponding Author:}

Ana Larissa Gomes Machado Email: analarissa2001@yahoo.com.br

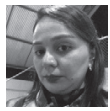

Submission: 05-29-2018 Approval: 02-13-2019

\begin{abstract}
Objective: Assess the level of health literacy of adults, with and without hypertension, treated in three basic health units (UBS) in Picos, Piauí. Methods: Cross-sectional study conducted with 357 adults. Data were collected using a questionnaire with sociodemographic variables, and literacy was assessed by the Test of Functional Literacy in Adults. Descriptive analysis was performed followed by the association between literacy and exposure variables with Pearson's chi-squared $\left(\mathrm{X}^{2}\right)$ test and MannWhitney U test. Results: Inadequate or marginal health literacy was found in three units investigated $(71.5 \% ; 77.8 \% \text { and } 85.2 \%)_{\text {; }}$. Age and the years of schooling were factors associated with inadequate literacy in adults with hypertension $(p<0.0001)$. Conclusion: Inadequate literacy was found in more than $70 \%$ of the hypertensive patients investigated. This finding reinforces the need to improve the self-care skills of hypertensive patients, especially the older ones and those with few years of schooling. Descriptors: Chronic disease, Hypertension, Health Literacy, Health Promotion, Primary Health Care.
\end{abstract}

\section{RESUMO}

Objetivo: Avaliar o nível de letramento em saúde de adultos, com e sem hipertensão, acompanhados em três Unidades Básicas de Saúde (UBS) de Picos, Piauí. Método: Estudo transversal realizado com 357 adultos. Para coleta de dados utilizou-se questionário com variáveis sociodemográficas, e o instrumento Test of Funcional Literacy in Adults para avaliar o letramento. Realizou-se análise descritiva seguida da associação entre letramento e variáveis de exposição com os testes $X^{2}$ de Pearson e Mann-Whitney. Resultados: Letramento inadequado ou marginal foi encontrado nas três unidades investigadas (71,5\%; $77,8 \%$ e $85,2 \%)$. Foram fatores associados ao letramento inadequado a idade e os anos de estudo nos adultos com hipertensão $(p<0,0001)$. Conclusão: O letramento inadequado foi encontrado em mais de $70 \%$ dos hipertensos investigados. Esse achado reforça a necessidade de melhorar as habilidades para o autocuidado dos hipertensos, principalmente naqueles com maior idade e menos anos de estudo.

Descritores: Doença crônica, Hipertensão, Alfabetização em Saúde, Promoção da Saúde, Atenção Primária à Saúde.

\section{RESUMEN}

Objetivo: evaluar el nivel de alfabetización en salud de adultos, con y sin hipertensión, tratados en tres unidades básicas de salud (UBS) en Picos, Piauí. Método: Estudio transversal realizado con 357 adultos. Los datos se recopilaron mediante un cuestionario con variables sociodemográficas, y la alfabetización se evaluó mediante la Prueba de Alfabetización Funcional en adultos. Se realizó un análisis descriptivo seguido de la asociación entre las variables de alfabetización y exposición con la prueba de chicuadrado de Pearson $\left(\mathrm{X}^{2}\right)$ y la prueba $\mathrm{U}$ de Mann-Whitney. Resultados: En las tres unidades investigadas $(71,5 \% ; 77,8 \%$ y $85,2 \%)$ se encontró una alfabetización de salud inadecuada o marginal. La edad y los años de escolaridad fueron factores asociados con una alfabetización inadecuada en adultos con hipertensión ( $p<0,0001)$. Conclusión: se encontró una alfabetización inadecuada en más del 70\% de los pacientes hipertensos investigados. Este hallazgo refuerza la necesidad de mejorar las habilidades de autocuidado de los pacientes hipertensos, especialmente los de mayor edad y aquellos con pocos años de escolaridad.

Descriptores: Enfermedad Crónica, Hipertensión, Alfabetización en Salud, Promoción de la Salud, Atención Primaria de Salud. 


\section{INTRODUCTION}

Health Literacy $(\mathrm{HL})$ is a multifaceted construct little explored in Brazil that comprises two main fields of knowledge: health and education. The field of health addresses the principles of health promotion, disease prevention and empowerment of individuals, while education is related to the literacy process ${ }^{(1)}$. $\mathrm{HL}$ is the ability to judge and make decisions about the care, prevention of diseases and health promotion, through knowledge, experience and ability to obtain, understand, assess and apply the information, in order to maintain or improve the quality of life ${ }^{(2)}$.

Skills such as writing, speaking, reading and performing mathematical calculations can be assessed by instruments that measure the $\mathrm{HL}^{(3)}$. These attributes are necessary for the care and improvement of the health conditions of individuals with chronic conditions, especially Hypertension $(\mathrm{HT})^{(4)}$.

The therapeutic segment of HT is related to the level of health literacy of individuals, because the ability to understand the medical information is highly significant to the maintenance of the state of health ${ }^{(5)}$. Studies show that $\mathrm{HL}$ contributes to the use of medications ${ }^{(6)}$, control of blood pressure ${ }^{(7-8)}$, practice of physical activity ${ }^{(9)}$ and reduction of mortality rates in patients with heart failure ${ }^{(10)}$.

We observed that the studies conducted in Brazil have assessed the $\mathrm{HL}$ of individuals in specific populations, such as adults and seniors $^{(1,11-12)}$, people with distinct health aggravations, such as diabetes ${ }^{(5,13)}$, cardiovascular diseases ${ }^{(14)}$ and chronic kidney disease $^{(15)}$, or in individuals in continuous use of medicines ${ }^{(16)}$, but only few studies assessed the $\mathrm{HL}$ of adults with hypertension ${ }^{(15)}$, in particular those who are treated in the Primary Health Care (PHC).

$\mathrm{PHC}$ is the first contact between population and health service and, in Brazil, the prevention, diagnosis, monitoring and control of the blood pressure pose challenges to the teams of Basic Attention (BA). The professionals of BA shall focus on the user's participation in the treatment, involving him/her in the definition and implementation of strategies to control high blood pressure ${ }^{(17)}$. Given this context, the HL of users contributes greatly to text reading and comprehension of the written and oral information provided by doctors, nurses and other health professionals to make decisions, use medicines properly and/or perform self-care ${ }^{(14)}$.

In general, people with chronic diseases present inadequate $\mathrm{HL}^{(6)}$, a number that may reach $41 \%$ among those with $\mathrm{HT}^{(7)}$, which can influence directly on adherence to interventions ${ }^{(18)}$ and on the knowledge about the disease ${ }^{(19)}$.

Thus, the fact of being hypertensive or not may involve important differences in people's lifestyle, with the power to directly influence self-care, such as the adoption of healthy eating habits and regular practice of physical activity. Given the magnitude of the problem, it is necessary to learn more about the $\mathrm{HL}$ of PHC users, establishing comparisons between the people who exhibit chronic health conditions, such as HT, and those who do not exhibit, in order to understand the factors that influence people's decision making and determine their self-care.

The assessment of the $\mathrm{HL}$ of individuals seeking treatment at the PCH can help subsidize health public policies based on the level of understanding of the users about the information provided in
Basic Health Units (UBS), which may influence the development of educational materials more accessible to social, cultural and educational contexts of the public assisted in that service ${ }^{(20)}$.

In addition, the knowledge of $\mathrm{HL}$ can contribute to the reorientation of health educational practices carried out by the professionals of the BA using active methodologies to share knowledge with hypertensive users about health care, using appropriate vocabulary and stimulating lifestyle changes, crucial to the therapeutic process and to conduct chronic health conditions.

\section{OBJECTIVE}

Assess the HL level of adults, with and without hypertension, treated in three UBS in Picos, Piauí.

\section{METHODS}

\section{Ethical aspects}

This study was approved by the Research Ethics Committee of the Federal University of Piauí.

\section{Study design, location, and period}

Cross-sectional survey carried out as part of the Research Project "Health Literacy of hypertensive adults: associated factors and pressure control," which was developed by scholarship holder of the Institutional Scientific Initiation Scholarship Program (PIBIC) of the Federal University of Piauí (UFPI), in Picos, from November 2016 to April 2017. We have selected three UBS located in different areas of the city of Picos, Piauí, two being located in urban area $(A$ and $B$ ) and one in the rural area (C). UBS were chosen in a draw, in order to investigate adults living in territories with distinct characteristics.

\section{Sample and inclusion criteria of participants}

The inclusion criteria comprised: individuals aged 18 years or more, with schooling greater than or equal to one year or informal education, registered and treated by the UBS included, seeking care at the time of the interview or addressed at home after consulting the register of UBS for adult users.

The sample was estimated at 357 adults, considering P of 50\%, because this value implies maximum sample size, a significance level of $5 \%(\alpha=0.05)$ and $8 \%$ relative sampling error (absolute sampling error $=4 \%$ ). After stratification of the sample, the following number of adults was obtained in each UBS: A-165; B-110 and C-82. Individuals who fulfilled the inclusion criteria, agreed to participate in the study and signed an informed consent form were selected.

\section{Study protocol}

The interviews were carried out in a reserved room in each UBS or at the user's home, using two data collection instruments. All the interviews were conducted by a nurse, scholarship holder of the PIBIC, previously trained on the procedures to be carried out. 
In the first instrument, sociodemographic data were investigated, while the second assessed the $\mathrm{HL}$, through the Brazilian version of the Test of Functional Health Literacy in Adults (STOFHLA). The S-TOFHLA test has 36 questions and is available in English ${ }^{(21-22)}$ and Spanish ${ }^{(23)}$, having been validated for use in Brazil in 2009 (24). It assesses the HL level of individuals, regardless of educational level, according to the score obtained with the questions about reading comprehension and ability to perform mathematical calculations, involving a situation common to the user in the field of health ${ }^{(25)}$.

The questions about the mathematical ability are punctuated by four items weighing 7, totaling a value of 28 points, and the questions about reading comprehension are punctuated by 36 items weighing 2, totaling 72 points. Thus, the S-TOFHLA test categorizes health literacy in three levels: inadequate ( 0 to 53 points), marginal (54 to 66 points) and adequate (67 to 100 points) ${ }^{(22)}$.

\section{Analysis of the results}

After data collection, a database was created in the Statistical Package for the Social Sciences program (SPSS) version 20.0. The variables were organized into (i) sociodemographic characteristics (sex, marital status, age, schooling, ethinicity and income); (ii) presence of HT (with and without HT), (iii) health literacy level (inadequate, marginal, adequate) and (iv) dimensions of Health Literacy (reading comprehension and mathematical ability).

For descriptive analysis of the data, the frequency of the variables, the mean, and the standard deviation (SD) for each dimension of the $\mathrm{HL}$ were determined. To analyze associations between HL and HT, the Pearson's chi-squared $\left(X^{2}\right)$ test and the Mann-Whitney test were used. For statistical significance, the value $\mathrm{p}<0.05$ was adopted.

\section{RESULTS}

We interviewed 357 adults from three UBS (A:165; B:110; $C: 82)$. Table 1 shows the sociodemographic characteristics of the participants, according to the UBS of origin. Women were predominant (72.9\%); they were aged between 18 and 39 years $(44.2 \%)$, married (60.8\%), with high schooling (38.2\%), self-proclaimed non-white $(71.7 \%)$ and with income less than a minimum wage $(57.1 \%)$.

About the association between hypertension and the health literacy level of participants, Table 2 shows that a statistically significant association was found between the variables in the three basic units investigated $(p<0.05)$. Inadequate or marginal $\mathrm{HL}$ obtained higher percentage among adults with $\mathrm{HT}$ in three UBS (71.5\%, 77.8\%; 85.2\%).

Table 1 - Frequency distribution of sociodemographic characteristics of adults with and without hypertension, per Basic Health Unit of origin. PicosPiauí, 2017

\begin{tabular}{|c|c|c|c|c|c|c|c|c|}
\hline & \multirow{2}{*}{$\begin{array}{l}\text { Código da unidade } \\
\text { Características }\end{array}$} & \multicolumn{2}{|c|}{$\begin{array}{c}A(n=165) \\
n(\%)\end{array}$} & \multicolumn{2}{|c|}{$\begin{array}{c}B(n=110) \\
n(\%)\end{array}$} & \multicolumn{2}{|c|}{$\begin{array}{c}C(n=82) \\
n(\%)\end{array}$} & \multirow{2}{*}{$\begin{array}{c}\text { Total } \\
(n=357) \\
n(\%)\end{array}$} \\
\hline & & $\begin{array}{c}\text { With } \\
\text { Hypertension }\end{array}$ & $\begin{array}{c}\text { Without } \\
\text { Hypertension }\end{array}$ & $\begin{array}{c}\text { With } \\
\text { Hypertension }\end{array}$ & $\begin{array}{c}\text { Without } \\
\text { Hypertension }\end{array}$ & $\begin{array}{c}\text { With } \\
\text { Hypertension }\end{array}$ & $\begin{array}{c}\text { Without } \\
\text { Hypertension }\end{array}$ & \\
\hline \multicolumn{9}{|l|}{ Sex } \\
\hline & Male & $8(19.5 \%)$ & $33(80.5 \%)$ & $11(36.7 \%)$ & 19(63.3\%) & $18(69.2 \%)$ & $8(30.8 \%)$ & $97(27.1 \%)$ \\
\hline & Female & $20(16.1 \%)$ & 104(83.9\%) & $25(31.2 \%)$ & $55(68.8 \%)$ & $43(76.8 \%)$ & $13(23.2 \%)$ & $260(72.9 \%)$ \\
\hline \multicolumn{9}{|l|}{ Age group } \\
\hline & $18-39$ & $6(5.7 \%)$ & $99(94.3 \%)$ & $1(2.7 \%)$ & $36(97.3 \%)$ & $5(31.2 \%)$ & $11(68.8 \%)$ & $158(44.2 \%)$ \\
\hline & $40-60$ & $18(33.3 \%)$ & $36(66.7 \%)$ & $23(42.6 \%)$ & $31(57.4 \%)$ & $30(79.0 \%)$ & $8(21.0 \%)$ & $146(40.9 \%)$ \\
\hline & $>60$ & $4(66.7 \%)$ & $2(33.3 \%)$ & $12(63.2 \%)$ & $7(36.8 \%)$ & $26(92.9 \%)$ & $2(7.1 \%)$ & $53(14.9 \%)$ \\
\hline \multicolumn{9}{|c|}{ Marital status } \\
\hline & Single & $8(12.5 \%)$ & $56(87.5 \%)$ & $4(15.4 \%)$ & $22(84.6)$ & 19(61.3\%) & $12(38.7 \%)$ & $121(33.9 \%)$ \\
\hline & Married & $17(17.3 \%)$ & $81(82.7 \%)$ & $28(35.0 \%)$ & $52(65.0 \%)$ & $30(76.9 \%)$ & $9(23.1 \%)$ & $217(60.8 \%)$ \\
\hline & Widow/widower & $3(100.0 \%)$ & - & $4(100.0 \%)$ & - & $12(100.0 \%)$ & - & $19(5.3 \%)$ \\
\hline \multicolumn{9}{|l|}{ Schooling } \\
\hline & Some Elementary or Middle School & $12(24.5 \%)$ & $37(75.5 \%)$ & $20(54.1 \%)$ & $17(45.9 \%)$ & $30(90.9 \%)$ & $3(9.1 \%)$ & $119(33.8 \%)$ \\
\hline & Elementary or Middle School & $3(7.3 \%)$ & $38(92.7 \%)$ & $2(15.4 \%)$ & $11(84.6 \%)$ & $7(63.6 \%)$ & $4(36.4 \%)$ & $65(18.4 \%)$ \\
\hline & High School & $8(12.7 \%)$ & $55(87.3 \%)$ & $12(26.1 \%)$ & $34(73.9 \%)$ & $15(57.7 \%)$ & $11(42.3 \%)$ & 135 (38.2\%) \\
\hline & College Degree & $3(30.0 \%)$ & $7(70.0 \%)$ & $2(15.4 \%)$ & $11(84.6 \%)$ & $8(72.7 \%)$ & $3(27.3 \%)$ & $34(9.6 \%)$ \\
\hline \multicolumn{9}{|l|}{ Ethnicity } \\
\hline & White & $5(13.5 \%)$ & $32(86.5 \%)$ & 13(39.4\%) & $20(60.6 \%)$ & $25(80.6 \%)$ & $6(19.4 \%)$ & $101(28.3 \%)$ \\
\hline & Other & $23(18.0 \%)$ & $105(82.0 \%)$ & $23(29.9 \%)$ & $54(70.1 \%)$ & $36(70.6 \%)$ & $15(29.4 \%)$ & $256(71.7 \%)$ \\
\hline \multicolumn{9}{|l|}{ Income } \\
\hline & $<1$ Minimum Wage & 19(15.4\%) & $104(84.6 \%)$ & 10(19.6\%) & $41(80.4 \%)$ & $21(70.0 \%)$ & $9(30.0 \%)$ & $204(57.1 \%)$ \\
\hline & 1 to 6 Minimum Wages & $9(21.4 \%)$ & $33(78.6 \%)$ & $26(44.1 \%)$ & $33(55.9 \%)$ & $40(76.9 \%)$ & $12(23.1 \%)$ & $153(42.9 \%)$ \\
\hline
\end{tabular}


After verifying the association between the means of $\mathrm{HL}$ and sociodemographic variables, we observed differences between the UBS of the study regarding the age and the years of schooling of adults (Table 3). The average age of adults with inadequate/ marginal $\mathrm{HL}$ were higher among hypertensive patients in units $B$ and $C(p<0.0001)$ and among non-hypertensive in units $A$ $(p<0001)$ and $B(p=0.02)$.

In relation to the years of schooling, we observed that the average age of adults with adequate $\mathrm{HL}$ were higher, especially among the hypertensive patients in units $B(p=0.003)$ and $C$ $(p<0.0001)$ and among non-hypertensive patients in the three units $(p<0.05)$ (Table 3$)$.

Table 2 - Association between hypertension and the health literacy level of participants, per Basic Unit of origin. Picos-Piauí, 2017

\begin{tabular}{|c|c|c|c|c|c|}
\hline \multirow{2}{*}{$\begin{array}{c}\text { Basic } \\
\text { Health } \\
\text { Units }\end{array}$} & \multirow[b]{2}{*}{ Hypertension } & \multicolumn{3}{|c|}{ Health Literacy Level } & \multirow{2}{*}{$\begin{array}{c}P \\
\text { value }\end{array}$} \\
\hline & & $\begin{array}{c}\text { Inadequate } \\
\text { n (\%) }\end{array}$ & $\begin{array}{c}\text { Marginal } \\
\text { n (\%) }\end{array}$ & $\begin{array}{c}\text { Adequate } \\
\text { n (\%) }\end{array}$ & \\
\hline \multirow[t]{2}{*}{ A } & Hypertensive & 19(67.9) & $1(3.6)$ & $8(28.6)$ & \multirow{2}{*}{0.025} \\
\hline & Non-hypertensive & $57(41.6)$ & $24(17.5)$ & $56(40.9)$ & \\
\hline \multirow[t]{2}{*}{ B } & Hypertensive & $27(75.0)$ & $1(2.8)$ & $8(22.2)$ & \multirow{2}{*}{0.002} \\
\hline & Non-hypertensive & $29(39.2)$ & $11(14.9)$ & $34(45.9)$ & \\
\hline \multirow[t]{2}{*}{ C } & Hypertensive & $46(75.4)$ & $6(9.8)$ & $9(14.8)$ & \multirow{2}{*}{0.002} \\
\hline & Non-hypertensive & $8(38.1)$ & $2(9.5)$ & $11(52.4)$ & \\
\hline
\end{tabular}

After examining the dimensions of Health Literacy, higher means were observed in the mathematical ability score among adults without $H T$ in unit $A(p=0.029)$ and in the reading comprehension score among adults without HT in the three UBS $(p<0.05)$ (Table 4).

\section{DISCUSSION}

This study assessed the Health Literacy of individuals with and without hypertension, treated by three UBS of the city of Picos, to verify the understanding of information related to the health of the adult population treated in PHC. The sociodemographic characteristics found in this study, such as the predominance of non-white and married women with low income were similar to other surveys conducted in Brazil ${ }^{(15,26,27)}$.

Young and non-hypertensive adults, with education compatible with eight years of schooling and with inadequate/marginal Health Literacy stood out in this survey. This profile reflects the importance of studying $\mathrm{HL}$ in the Brazilian population, since some skills are required for self-care and are associated with better outcomes in health, such as the understanding of written or spoken information about health, medical prescriptions, and the ability to perform simple mathematical calculations to count drug doses or the amount of calories in a diet.

In Brazil, there is not a research of national amplitude showing the HL level of the population ${ }^{(4)}$; however, there are studies that

Table 3 - Association between sociodemographic variables and the average scores of health literacy of the participants in the study, with and without hypertension, per Basic Health Unit. Picos-Piauí, 2017

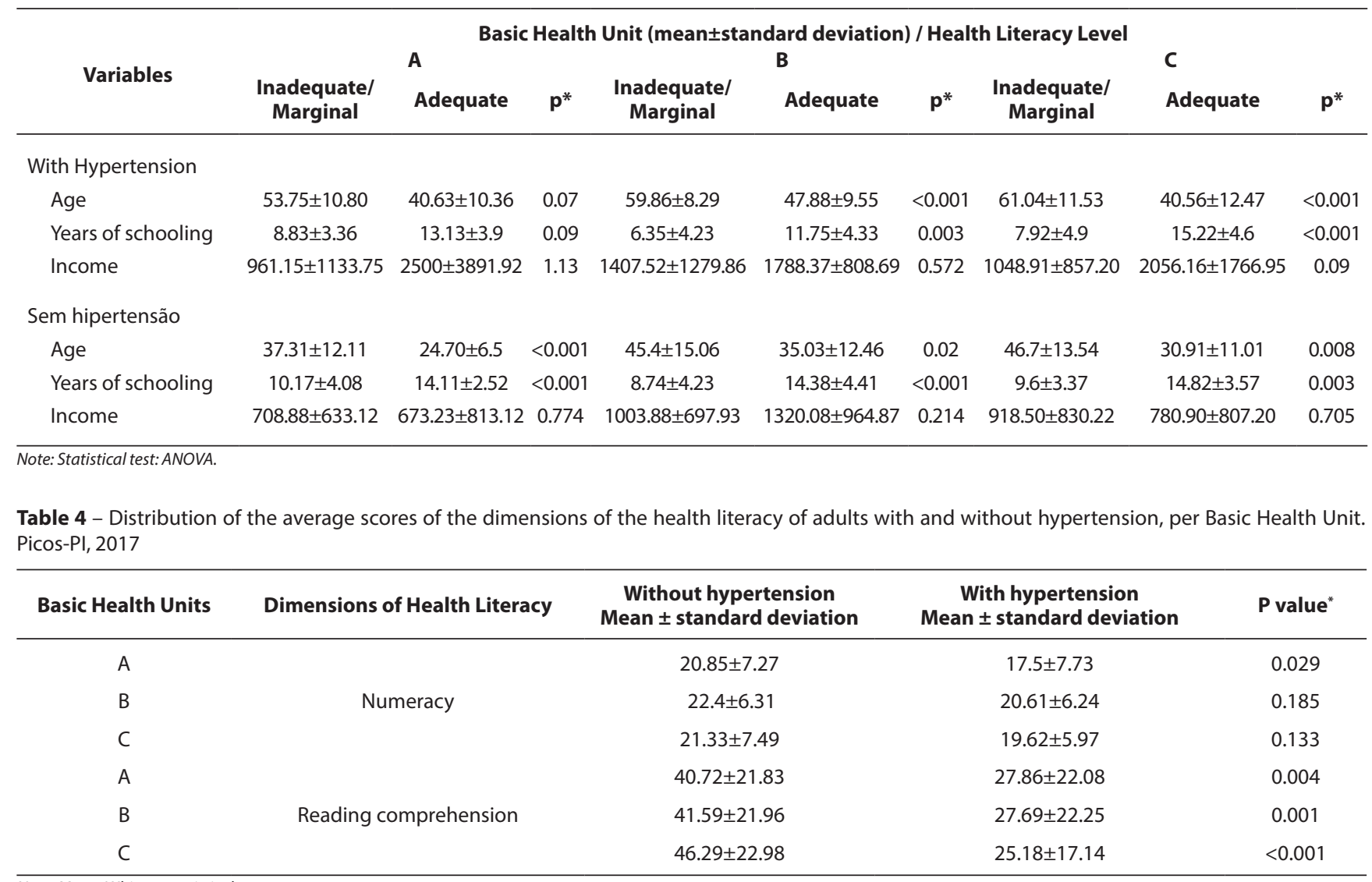

Note: Mann-Whitney statistical test. 
validated measurement instruments of this construct for the Portuguese language ${ }^{(12)}$ and classified levels of health literacy of people with specific health problems ${ }^{(5,11,14)}$.

Considering the relevance of this theme for the self-care of people with chronic health conditions, studies show that $\mathrm{HL}$ is a key component of the set of skills needed to improve medication adherence and self-management of chronic diseases, and control hypertension ${ }^{(7)}$.

According to the findings of this research, several studies that classified the literacy through S-TOFHLA also found limited or inadequate Health Literacy of the individuals investigated, such as the research conducted with patients with chronic kidney disease in pre-dialytic treatment, in which all participants showed inadequate literacy ${ }^{(15)}$; a study conducted in Fortaleza, $C E$, with adults, showed very low reading ability of respondents, so they would not know or would have difficulties to deal with texts in their daily lives ${ }^{(1)}$, and the National Survey assessed the literacy, in English, of a sample of American adults over the age of 16 years ${ }^{(28)}$.

Comparing the limited $\mathrm{HL}$ of the participants in this research with other Brazilian studies that also used instruments to measure the literacy, we observed great diversity of results, including a research using the SAHLPA-50, a measurement instrument validated for the Portuguese language ${ }^{(12)}$, in which $66 \%$ of the population investigated showed inadequate Health Literacy.

Data from international study ${ }^{(29)}$ show that in the United Kingdom, in the United States, in Australia and in Canada, 20\% to $50 \%$ of the population has low level of $\mathrm{HL}$, which may compromise the individual and collective health status, resulting in low adherence to measures for health promotion, low levels of knowledge about chronic health conditions and low capacity to manage their own health and illness process ${ }^{(30-31)}$.

In this study, the association between hypertension and HL level of the participants was observed, highlighting the high percentage of people with $\mathrm{HT}$ who have inadequate level of $\mathrm{HL}$ in three UBS, where the research was carried out $(A: p=0.025 ; B: p=0.002 ; C$ : $\mathrm{p}=0.002$ ). These people need health care, which cannot be delegated to others, that is, their involvement is required to control the blood pressure through lifestyle changes, including a therapeutic itinerary that involves medications, regular physical activity and diet control.

For all activities scored, the inadequate $\mathrm{HL}$ presented by participants may compromise the success of the treatment. It is necessary therefore to consider that these individuals are looking for information in health services, which are provided in writing or verbally, and, in this case, the limitations of HL can embarrass users or hinder the understanding of information ${ }^{(4)}$.

It is noteworthy that participants with HT were predominantly older and with less schooling, so the association between HT and $\mathrm{HL}$ found in this study may be attributed to factors such as age and years of schooling, and not just the fact of being or not being hypertensive, as shown in the results. Meta-analysis performed with sixty international studies showed that older age is strongly associated with inadequate $\mathrm{HL}$ in studies that assessed comprehension, reasoning and mathematics skills (OR: 4.20; $95 \% \mathrm{Cl})^{(32)}$. Older adults are vulnerable regarding $\mathrm{HL}$, especially in relation to cognitive and behavioral skills to manage external resources in such a way that the physical and social well-being is maintained or restored ${ }^{(33-34)}$.
As to education, those people with few years of schooling showed the worst levels of $\mathrm{HL}$, since they may have trouble understanding the words used by professionals, resulting in less knowledge about their health condition ${ }^{(19)}$, preventive measures and medication adherence ${ }^{(18)}$. When it comes to people with hypertension, for example, these precautions are essential, and patients with limited literacy may not use judiciously the information to promote and maintain good health ${ }^{(4,35)}$.

As for the dimensions of literacy, we observed that the scores for mathematical skills and reading comprehension were higher in the three units investigated among the participants who did not have hypertension, reinforcing the association between inadequate literacy and hypertension. This difference shows a greater ease in reading and comprehension of written information in detriment to the ability of performing mathematical calculations.

Given the level of education presented by most participants in this study - high school-, we expected them to have little difficulty in understanding both passages of S-TOFHLA; however, we observed that the ability to calculate posed some kind of challenge to the respondents. In accordance with the findings of this study, participants in another research presented low mathematical skills $\mathbf{s}^{(5,36-37)}$.

Several other studies showed that not always the level of schooling ensures the level of literacy expected, although low levels of $\mathrm{HL}$ may be associated with fewer years of schooling, as shown in this study ${ }^{(32,38-40)}$.

The abilities assessed by S-TOFHLA, reading and mathematical skills, when considered in national survey, separately, proved to be inadequate in the population, although the individuals knew how to read and write, they did not present reading, writing and calculation skills to be fully inserted into the literate society ${ }^{(40)}$. Thus, the relationship between reading and mathematical skills goes beyond logical deductions and highlights the importance of knowing the profile of the population treated at $\mathrm{PCH}$ regarding this indicator.

As to health care, as important as patients' literacy ability are the communication skills of health professionals, especially considering that the training of users for self-care involves dialogue between users, professionals and health systems. Thus, the quality of health care and the successful management of chronic conditions include understanding the information that is relevant to the conditions of the patients, whether acute or chronic.

\section{Limitations of the study}

One of the limitations of the research is the cross-sectional approach, which involves collecting data at a single point in time, without observing the participants according to the analysis variables. In addition, the number of literate adults who could respond to S-TOFHLA was reduced, being difficulty to gather a sample of primary care users and verify their level of health literacy. However, the results have contributed to show the low Health Literacy level of participants could harm the functioning of the Unified Health System (SUS), since the success of the activities depends on the collaboration and support of users, for whom these activities are directed.

\section{Contributions to the field of Health}

In the field of health, this study contributes to developing knowledge and discussions about the importance to improve the 
$\mathrm{HL}$ levels of users at $\mathrm{PCH}$, which should be promoted by healthcare professionals and public managers. These actions include (i) to consider $\mathrm{HL}$ on the agenda of public health policies in Brazil; (ii) carry out educational activities in communities to raise the $\mathrm{HL}$ level of users of SUS and, consequently, improve the user-professionalhealth system interaction, aiming to enhance the Brazilian public health system; and (iii) improve the actions for health promotion and prevention of chronic conditions, regarding planning, implementation and assessment, based on the knowledge and elevation of the $\mathrm{HL}$ of the population. These measures may bring benefits and reflect positively on people's health and must be a priority for the actors involved in the context of primary health care.

\section{CONCLUSION}

Inadequate literacy was found in more than $70 \%$ of the hypertensive patients investigated. This finding reinforces the need to improve the self-care skills of hypertensive patients, especially the older ones and those with few years of schooling.

The results of this study show that educational materials whose readability is appropriate to the level of literacy of users of SUS must be developed. Furthermore, the measures for health promotion and prevention of chronic conditions should aim at (i) situational diagnosis of the health literacy of the target population so that they can achieve the objectives proposed; (ii) the improvement of the professional-user interaction, emphasizing the oral and written communication; and (iii) the inclusion of the community and the family in the healthcare process.

\section{ACKNOWLEDGEMENTS}

To National Council for Scientific and Technological Development (CNPq) for the Research scholarship that enabled the realization of part of this study.

\section{REFERENCES}

1. Passamai MPB, Sampaio HAC, Lima WO. Letramento funcional em saúde de adultos no contexto do Sistema Único de Saúde. Fortaleza: EdUECE; 2013.

2. Sorensen K, den Broucke SV, Fullam J, Doyle G, Pelikan J, Slonska Z, Brand H, HLS-EU Consortium Health Literacy Project European. Health literacy and public health: a systematic review and integration of definitions and models. BMC Public Health [Internet]. 2012 [cited 2017 Ago 10];12:80. Available from: https://doi.org/10.1186/1471-2458-12-80

3. Machado ALG, Lima FET, Cavalcante TF, Araújo TL, Vieira NFC. [Instruments of health literacy used in nursing studies with hypertensive elderly]. Rev Gaúcha Enferm [Internet]. 2014 [cited 2017 Aug 08];35(4):101-7. Available from: http://dx.doi.org/10.1590/19831447.2014.04.45139 Portuguese

4. Passamai MPB, Sampaio HAC, Dias AMI, Cabral LA. Functional Health Literacy: Reflections and concepts on its impact on the interaction among users, professionals and the health system. Interface [Internet]. 2012 [cited 2017 Aug 10];16(41):301-14. Available from: http://dx.doi. org/10.1590/S1414-32832012005000027

5. Sampaio HAC, Carioca AAF, Sabry MOD, Santos PM, Coelho MAM, Passamai MPB. [Health literacy in type 2 diabetics:associated factors and glycemic control]. Ciênc Saude Colet [Internet]. 2015[cited 2017 Sep 11];20(3):865-874. Available from: doi:10.1590/141381232015203.12392014 Portuguese.

6. Miller TA. Health literacy and adherence to medical treatment in chronic and acute illness: a meta-analysis. Patient Educ Couns [Internet]. 2016 [cited 2017 Oct 27];99(7):1079-86. Available from: https://doi.org/10.1016/j.pec.2016.01.020

7. McNaughton CD, Jacobson TA, Kripalani S. Low literacy is associated with uncontrolled blood pressure in primary care patients with hypertension and heart disease. Patient Educ Couns [Internet]. 2014 [cited 2017 Sep 21];96(2):165-170. Available from: doi:10.1016/j. pec.2014.05.007

8. Halladay JR, Donahue KE, Cené CW, Li Q, Cummings DM, Hinderliter AL, et al. The association of health literacy and blood pressure reduction in a cohort of patients with hypertension: the heart healthy lenoir trial. Patient Educ Couns [Internet]. 2017 [cited 2017 Nov 06];100(3):542-9. Available from: https://doi.org/10.1016/j.pec.2016.10.015

9. Plummer LC, Chalmers KA. Health literacy and physical activity in women diagnosed with

10. breast cancer. Psychooncology [Internet]. 2016 [cited 2017 Nov 06];26(10):1478-83. Available from: https://doi.org/10.1002/pon.4318

11. Moser DK, Robinson S, Biddle MJ, Pelter MM, Nesbitt T, Southard J, et al. Health literacy predicts morbidity and mortality in rural patients with heart failure. J Card Fail [Internet]. 2015 [cited 2017 Aug 10];21(8):612-8. Available from: https://doi.org/10.1016/j.cardfail.2015.04.004

12. Paskulin LMG, Bierhals CCBK, Valer DB, Aires M, Guimarães NV, Brocker AR, et al. [Health literacy of older people in primary care]. Acta Paul Enferm [Internet]. 2012 [cited 2017 Aug 11];25(Special Issue 1):129-35. http://dx.doi.org/10.1590/S0103-21002012000800020 Portuguese.

13. Apolinario D, Braga RCOP, Magaldi RM, Busse AL, Campora F, Brucki S, et al. Short assessment of health literacy for portuguesespeaking adults. Rev Saude Pública [Internet]. 2012 [cited 2017 Aug 20];46(4):702-11. Available from: http://dx.doi.org/10.1590/ S0034-89102012005000047

14. Souza JG, Apolinario D, Farfel JM, Jaluul O, Magaldi RM, Busse AL, et al. Applicability of the spoken knowledge in low literacy patients with diabetes in brazilian elderly. Einstein [Internet]. 2016 [cited 2017 Oct 12];14(4):513-9. Available from: https://doi.org/10.1590/ S1679-45082016AO3747 
15. Neto CJA, Pinto FAR, Bignoto TC, Costa LA, Vieira CIR, Estevanin GM, et al. [Functional health literacy in chronic cardiovascular patients]. Ciênc Saude Colet [Internet]. 2017 [cited 2017 Oct 12]; Available from: http://www.cienciaesaudecoletiva.com.br/artigos/letramentofuncional-em-saude-nos-portadores-de-doencas-cardiovasculares-cronicas/16286?id=16286 Portuguese.

16. Moraes KL, Brasil VV, Oliveira GF, Cordeiro JABL, Silva AMTC, Boaventura RP, et al. Functional health literacy and knowledge of renal patients on pre-dialytic treatment. Rev Bras Enferm [Internet]. 2017 [cited 2017 Nov 08];70(1):147-53. Available from: http://dx.doi. org/10.1590/0034-7167-2015-0169

17. Martins MAP, Costa JM, Mambrini JVM, Ribeiro ALP, Benjamin EJ, Brant LCC, et al. Health literacy and warfarin therapy at two anticoagulation clinics in brazil. Heart [Internet]. 2017 [cited 2017 Nov 08];103(14):1089-95. Available from: https://doi.org/10.1136/heartjnl-2016-310699

18. Ministério da Saúde (BR). Estratégias para o cuidado da pessoa com doença crônica: hipertensão arterial sistêmica [Internet]. Brasília (DF): Ministério da Saúde, 2013 [cited 2019 Mar 15]. Available from: http://bvsms.saude.gov.br/bvs/publicacoes/estrategias_cuidado_pessoa_ doenca_cronica.pdf

19. Geboers B, Brainard JS, Loke YK, Jansen CJM, Salter C, Reijneveld AS, et al. The association of health literacy with adherence in older adults, and its role in interventions: a systematic meta-review. BMC Public Health [Internet]. 2015 [cited 2018 Jan 07];15:903. Available from: https:// doi.org/10.1186/s12889-015-2251-y

20. Reading SR, Go AS, Fang MC, Singer DE, Liu IA, Black MH, et al. Health literacy and awareness of atrial fibrillation. J Am Heart Assoc [Internet]. 2017 [cited 2018 Jan 08];6(4):e005128. Available from: https://doi.org/10.1161/JAHA.116.005128

21. Baker DW, Williams MV, Parker RM, Gazmararian JA, Nurss J. Development of a brief test to measure functional health literacy. Patient Educ Couns [Internet]. 1999 [cited 2018 Jan 08];38(1):33-42. Available from: https://doi.org/10.1016/S0738-3991(98)00116-5

22. Parker RM, Baker DW, Williams MV, Nurss Jr The test of functional health literacy in adults: a new instrument for measuring patients' literacy skills. J Gen Intern Med [Internet]. 1995 [cited 2018 Jan 12];10(10):537-41. Available from: https://doi.org/10.1007/BF02640361

23. Rivero-Méndez M, Suárez E, Solís-Báez SS, Hernández G, Cordero W, Vázquez I, et al. Internal consistency of the spanish health literacy test (TOFHLA-SPR) for puerto rico. P R Health Sci J [Internet]. 2010 [cited 2017 Dec 12];29(1):49-53. Available from: https://www.ncbi.nlm.nih. gov/pmc/articles/PMC2853912/pdf/nihms190622.pdf

24. Carthery-Goulart MT, Anghinah R, Areza-Fegyweres R, Bahia VS, Brucki SM, Damin A, et al. Performance of a brazilian population on the test of functional health literacy in adults. Rev Saude Publica [Internet]. 2009 [cited 2018 Feb 20];43(4):631-8. Available from: http://dx.doi. org/10.1590/S0034-89102009005000031

25. Carthery-Goulart MT, Mialhe, FL. Letramento em saúde e promoção da saúde. In: Pelicione MCF, Mialhe FL, compilers. Educação e promoção da saúde: teoria e prática. São Paulo: Santos; 2012.

26. Carvalho MAN, Silva IBS, Ramos SBP, Coelho LF, Gonçalves ID, Figueiredo Neto JA. Quality of Life of Hypertensive Patients and Comparison of two Instruments of HRQOL Measure. Arq Bras Cardiol [Internet]. 2012 [cited 2018 Feb 20];98(5):442-51. Available from: http://dx.doi. org/10.1590/S0066-782X2012005000032

27. United States Department of Health and Human Services (USHHS). Office of disease prevention and health promotion. National action plan to improve health literacy. Washington, DC: USHHS; 2010.

28. Arruda LM, Oliveira JM, Cotta RMM, Ribeiro SMR. [Health and social profile of hypertensive patients enrolled in the family health strategy, divinésia, minas gerais]. Rev APS [Internet]. 2015 [cited 2017 Sep 12];18(1):78-84. Available from: https://aps.ufj.emnuvens.com.br/aps/ article/view/2220/862 Portuguese

29. Jovic-Vranes A, Bjegovic-Mikanovic V, Marinkovic J. Functional health literacy among primary health-care patients: data from the belgrade pilot study. J Public Health [Internet]. 2009 [cited 2017 Dec 04];31(4):490-5. Available from: https://doi.org/10.1093/pubmed/fdp049

30. World Health Communication Associates (WHCA). Health literacy: part 2 evidence and case studies. WHCA; 2010.

31. Kobayashi LC, Wardle J, Wolf MS, Wagner CV. Cognitive function and health literacy decline in a cohort of aging english adults. J Gen Intern Med [Internet]. 2015[cited 2018 Feb 07];30(7):958-64. Available from: https://doi.org/10.1007/s11606-015-3206-9

32. Ownby RL, Waldrop-Valverde D, Taha J. Why is health literacy related to health? An exploration among u.s. national assessment of adult literacy participants 40 years of age and older. Educ Gerontol [Internet]. 2012 [cited 2018 Feb 07];38(11):776-87. Available from: https://doi. org/10.1080/03601277.2011.645441

33. Kobayashi LC, Wardle J, Wolf MS, Wagner CV. Aging and functional health literacy: a systematic review and meta-analysis. J Gerontol B Psychol Sci Soc Sci [Internet]. 2016 [cited 2018 Mar 02];71(3):445-57. Available from: https://doi.org/10.1093/geronb/gbu161

34. Santos MIP, Portella MR. Conditions of functional health literacy of an elderly diabetics group. Rev Bras Enferm [Internet]. 2016 [cited 2018 Mar 03];69(1): 144-52. Available from: http://dx.doi.org/10.1590/0034-7167.2016690121i

35. McNaughton CD, Kripalani S, Cawthon C, Mion LC, Wallston KA, Roumie CL. Association of health literacy with elevated blood pressure: a cohort study of hospitalized patients. Med Care [Internet]. 2014 [cited 2018 Feb 15];52(4):346-53. Available from: https://doi.org/10.1097/ MLR.0000000000000101

36. Lipkus IM, Peters E, Kimmick G, Liotcheva V, Marcom P. Breast cancer patients' treatment expectations after exposure to the decision aid program adjuvant online: the influence of numeracy. Med Decis Making [Internet]. 2010 [cited 2018 Mar 12];30(4):464-73. Available from: https://doi.org/10.1177/0272989X09360371

37. Schapira MM, Neuner J, Fletcher KE, Gilligan MA, Hayes E, Laud P. The relationship of health numeracy to cancer screening. J Canc Educ 
[Internet]. 2011 [cited 2018 Mar 12];26(1):103-10. Available from: https://doi.org/10.1007/s13187-010-0133-7

38. Osborn CY, Cavanaugh K, Wallston KA, Rothman RL. Self-efficacy links health literacy and numeracy to glycemic control. J Health Commun [Internet]. 2010 [cited 2018 Feb 21];15(Supl 2):146-58. Available from: https://doi.org/10.1080/10810730.2010.499980

39. Cornett S. Assessing and addressing health literacy. Online J Issues Nurs [Internet]. 2009 [cited 2018 Feb 21];14(3 Manuscript 2):1-13. Available from: https://doi.org/10.3912/OJIN.Vol14No03Man02

40. Puntoni S. Health literacy in Wales: a scoping document for Wales. Wales: Welsh Assembly Government; 2010.

41. Instituto Paulo Montenegro, IBOPE Inteligência, Ação Educativa. INAF BRASIL 2011: Indicador de Alfabetismo Funcional: principais resultados. [Internet]. São Paulo: Instituto Paulo Montenegro, IBOPE Inteligência, Ação Educativa; 2012 [cited 2018 Jan 06]. 25 p. Available from: https://drive.google.com/file/d/OB5WoZXXFQTCRWE5UY2FiMzFhZEk/view 